\title{
IGFBP1 wt Allele
}

National Cancer Institute

\section{Source}

National Cancer Institute. IGFBP1 wt Allele. NCI Thesaurus. Code C52280.

Human IGFBP1 wild-type allele is located within 7p13-p12 and is approximately $5 \mathrm{~kb}$ in length. This allele, which encodes insulin-like growth factor-binding protein 1, plays a role in insulin-like growth factor regulation and interactions involving cell surface receptors. 